\title{
Mussel and oyster culture in Saldanha Bay, South Africa: potential for sustainable growth, development and employment creation
}

\author{
David Olivier • Lindy Heinecken • Sue Jackson
}

Received: 1 November 2012 / Accepted: 21 January 2013 / Published online: 16 February 2013

(C) The Author(s) 2013. This article is published with open access at Springerlink.com

\begin{abstract}
Worldwide declines in fish stocks have a significant impact on the livelihoods of coastal fishing communities as jobs are lost and alternative forms of employment are limited. Mariculture (marine aquaculture) is considered by governments to be a viable solution to address unemployment and poverty in such communities. In Saldanha Bay, South Africa, the growing mussel and oyster industry has considerable potential for poverty alleviation, hence food security enhancement. In the first part of this study, we examine the potential ecological carrying capacity of the Bay to produce bivalves, and estimate the impact of this on employment creation should the sector's growth potential be fully realised. This growth potential could take the sector to 10 to 28 times its current size, providing direct employment for 940 to 2,500 people in the Saldanha area. Secondly, we assess five factors that affect the sustainable growth, development and employment creation potential of small-scale mariculture in South Africa and other countries. These are state support, markets, funding, the natural environment and the local community. Participants in the sector perceive its expansion potential to be hampered by regulatory issues such as incomplete implementation of a cohesive and accessible financial support policy, slow processing of mandatory samples required to monitor product safety, poor facilitation of access to international markets, price undercutting by imports subsidized in their
\end{abstract}

We would like to thank and acknowledge Stellenbosch University Food Security Initiative HOPE project for funding that enabled the research to be undertaken.

D. Olivier $\cdot$ L. Heinecken

Department of Sociology and Social Anthropology,

Stellenbosch University, Stellenbosch, South Africa

S. Jackson $(\square)$

Department of Botany and Zoology, Stellenbosch University,

Stellenbosch, South Africa

e-mail: sjack@sun.ac.za countries of origin, and injuriously high lease fees for water levied by the parastatal harbour authority, coupled with lack of medium- and long-term lease tenure. The risk of environmental degradation from competing harbour use by large, fossil fuel and ore transport industries is of potential future concern.

Keywords Mariculture · South Africa · Development . Sustainability $\cdot$ Employment creation

\section{Introduction}

In South Africa, as in other countries, coastal fishing communities are experiencing rising unemployment as fish stocks decline (Costa-Pierce 2008; Naylor et al. 2000; Pitcher and Calder 1998; Rönnbäck et al. 2002). Such communities are characterised by their low average household income, high levels of food insecurity and relative isolation - all causes for growing concern because of the shortage of alternative livelihoods (Van Zyl et al. 2008). In this regard, mariculture (the farming of marine organisms) is sometimes considered a sustainable alternative to the fishing of wild stocks (Naylor et al. 2000), replacing jobs lost as fishing industries decline and often employing more individuals per unit of production than wild-catch fisheries (Britz 2007). The South African government has thus come to view mariculture as a means to address the rising unemployment in rural fishing communities (Joemat-Pettersson 2010).

The coastal town of Saldanha on South Africa's West Coast has been identified as a prime site for mussel and oyster culture. The nature of its waters gives Saldanha Bay considerable potential for the growth of this sector, as it is part of the Benguela Large Marine Ecosystem. In summer, strong winddriven coastal upwellings bring cold nutrient-rich water to the surface, providing a productive environment for phytoplankton 
growth as the water moves northwards. Pulses of this rich water move into the Big Bay section of Saldanha Bay every 6-10 days (Monteiro et al. 1998), creating a sheltered yet well-circulated environment that is one of few suitable for oyster and mussel culture in South Africa (Probyn et al. 2001). In fact, Saldanha Bay is among only four sites used for the culture of Pacific oysters (Crassostrea gigas) in South Africa, and the Bay's four farms currently contribute more to national oyster production than all other sites combined. It is also the major site for the commercial production of the Mediterranean mussel (Mytilus galloprovincialis, Britz et al. 2009).

A combination of the most recently available phytoplankton and mussel production estimates suggest that the Bay has the capacity to support considerably more than the bivalve biomass presently cultured there (Grant et al. 1998; Heasman et al. 1998; combined in Table 1 of our study). These values are from 1994 to 1995 and, providing they are used with caution (see below), give us a starting point for estimation of the development potential of this sector, which has been expanding countrywide since 2005 (Britz et al. 2009).

Assessment of the sustainability of such expansion in the favourable environment of Saldanha Bay is timely: in addition to the potential for revenue generation, bivalve culture employs a high proportion of relatively unskilled labour, and so can provide alternative employment in a community which has seen rising unemployment following recent downscaling of the West Coast anchovy, pilchard and hake fisheries. For example, a recent study of an informal settlement (Middelpos) in Saldanha, reported an average household monthly income of R1346, with $34 \%$ of employed people in the sample working in either fishing or aquaculture. Unemployment was 50-60\% (Vorster and Heinecken 2009).

Increased reliance on aquaculture rather than fishing has the potential to improve job security in this area, but our surveys and literature review together indicate that five key factors influence the sector's potential for sustainable development, hence employment creation. These are the state, the market, funding, unpredictable environmental challenges, and the local community.

With this background, the aims of our study were threefold: estimation of the biological growth potential (production or ecological carrying capacity) for mussel and oyster bivalve culture in Saldanha Bay, translation of this into employment growth potential of the industry, and identification of non-biological constraints to such growth. We did the following:

a) Conducted a literature review to estimate ecological carrying capacity for bivalves (mussels and oysters) in the Bay;

Table 1 Stepwise procedure used to estimate the employment potential of the bivalve culture industry in Saldanha Bay from previously published estimates of bivalve production, in conjunction with areas allocated for mariculture

\begin{tabular}{|c|c|c|}
\hline \multicolumn{2}{|l|}{ Factor } & \multirow{2}{*}{$\begin{array}{l}\text { Explanation and source } \\
\begin{array}{l}170 \text { ha of productive leased water area, mixed rafts and } \\
\text { long-lines (this study) }\end{array}\end{array}$} \\
\hline $\begin{array}{l}\text { Total annual bivalve production in } 2010 \text { (tons } \\
\text { live mass, mussels and oysters combined) }\end{array}$ & $1,176^{\mathrm{a}}$ & \\
\hline Area allocated to mariculture 2010 & 345 ha & A.F.G. Tonin, personal communication \\
\hline Total number of jobs in oyster and mussel sectors, 2010 & 89 & $\begin{array}{l}\text { This study (Table } 2 \text {, including directors, excluding post- } \\
\text { harvest mussel processing company) }\end{array}$ \\
\hline $\begin{array}{l}\text { Estimated } 1994-1995 \text { potential bivalve production } \\
\text { for } 415 \text { ha then available for culture (tons live mass } \\
\text { per year) }\end{array}$ & $15,000-40,000$ & Froget 1998 (unpublished) \\
\hline $\begin{array}{l}\text { Estimated } 2010 \text { potential bivalve production for } 345 \text { ha } \\
\text { (tons live mass per year) }\end{array}$ & $12,470-33,253$ & $\begin{array}{l}\text { Multiplication of } 1994-1995 \text { estimated potential production } \\
\text { by } 345 / 415=0.831\end{array}$ \\
\hline $\begin{array}{l}\text { Factor by which this exceeds total actual production in } \\
2010\end{array}$ & $10.6-28.3$ & \\
\hline $\begin{array}{l}\text { Potential number of jobs sustained by bivalve sector } \\
\text { should production expand to full potential }\end{array}$ & $943-2,518$ & $\begin{array}{l}89 \times \text { factor in previous row: assuming production:employee } \\
\text { ratio remains constant }\end{array}$ \\
\hline Number of dependents directly supported by each job & $2,830-7,554$ & $\begin{array}{l}3 \text { dependents per job, FAO (2009) value; agrees with mean } \\
\text { number per household of } 3.8 \text { (Vorster and Heinecken (2009) }\end{array}$ \\
\hline $\begin{array}{l}\text { Potential total number of people locally supported by } \\
\text { bivalve mariculture }\end{array}$ & $3,773-10,072$ & Number of direct jobs + number of dependents \\
\hline Percentage of Saldanha's total 2010 population estimate & $4.3-11.4$ & $\begin{array}{l}\text { Saldanha Bay Municipality (2007), projected value for } 2010 \\
\text { population of } 88 \text { 566, includes St Helena, Paternoster, Vredenburg, } \\
\text { Jacobsbaai, Hopefield, and Langebaan }\end{array}$ \\
\hline
\end{tabular}

${ }^{a} 1,000 \mathrm{t}$ of mussels annually, and $176 \mathrm{t}$ of oysters (live shell-on mass)

${ }^{\mathrm{b}}$ Rafts and long-lines in existing water lease area not stocked to maximum capacity 
Table 2 Industry employment profile partitioned by post level and gender

\begin{tabular}{|c|c|c|c|c|c|c|}
\hline \multirow[b]{2}{*}{ Position } & \multicolumn{2}{|l|}{ Male } & \multicolumn{2}{|l|}{ Female } & \multicolumn{2}{|c|}{ Total posts } \\
\hline & Number & $\%$ of post level & Number & $\%$ of post level & Number & $\%$ of all employees $\&$ directors \\
\hline Labour: permanent & 58 & 87 & 9 & 13 & 67 & 75 \\
\hline Labour: casual & 0 & 0 & 3 & 100 & 3 & 3 \\
\hline Supervisor & 6 & 86 & 1 & 14 & 7 & 8 \\
\hline Skipper & 4 & 100 & 0 & 0 & 4 & 4 \\
\hline Secretary & 0 & 0 & 1 & 100 & 1 & 1 \\
\hline Total employees & 68 & 83 & 14 & 17 & 82 & \\
\hline Directors & 6 & 86 & 1 & 14 & 7 & 8 \\
\hline Industry Total & & & & & 89 & \\
\hline
\end{tabular}

b) Interviewed employees and managers of all existing businesses in the sector to detail the employment profile at current production levels;

c) Used this profile to estimate future job creation potential of the sector, should production approach the ecological carrying capacity estimated in (a);

d) Used our survey and interview results to identify further constraints to the bivalve mariculture sector in Saldanha Bay, drawing parallels with case studies of mariculture elsewhere in the world.

Accordingly, the first section of the study estimates the ecological growth capacity and employment creation potential of the sector, based on the marine ecology literature and production estimates obtained in interviews with employers and employees in the industry. The second section examines five major policy-related, social or economic influences on the sustainability, growth and employment potential of bivalve mariculture in Saldanha Bay, with the aim of identifying sector-specific constraints.

\section{Research methodology}

Fieldwork took place from November 2010 to May 2011 and comprised semi-structured individual interviews with two liaison officers working at the interface between the bivalve mariculture sector and the state (hereafter referred to as "state representatives") (Appendix A), and with directors of all five bivalve mariculture farms in Saldanha Bay (hereafter, "directors") (Appendix B). The third interviewee group comprised 28 employees representing $34 \%$ of the entire 82-strong labour force (excluding directors, Appendix C). The sample was representative of the entire sector profile in terms of race, gender and level of education. The employee sample consisted of 20 male and five female labourers, one male and one female supervisor and one male skipper. Twenty-seven of the 28 employees were black. The average level of education for the sample was grade nine. Seventy-five percent of the sample had been living in Saldanha for 5 years or more. All the employees were permanent employees and not casual or part-time labourers as most employees in this sector are permanent.

The operational constraints of small businesses meant that these workers could not be interviewed individually during working hours. As a compromise, semi-structured focus group discussions were conducted on-site with available employees. One focus group discussion was held at each of the five companies. This took place in private and employees were asked to comment on a range of factors influencing their employment. All information was recorded anonymously.

State representatives and farm directors were asked about the influence of each of five factors identified as potential contraints, namely the state, the market, funding, the natural environment and the local community, on mariculture in Saldanha. In addition, farm directors were asked about annual production and employee totals, which were used to estimate the employment potential of the sector.

\section{Ecological carrying capacity and employment creation potential}

For the purposes of our study, we define (ecological) carrying capacity as the live mass of bivalves that can be supported by the primary (phytoplankton) production of a marine system (Grant et al. 1998) without depleting that production. In coastal waters, if nutrients such as nitrate are not in short supply, conditions are suitable for phytoplankton growth, and overstocking is avoided, culture of bivalve molluscs (oysters, mussels and clams) can produce a high-value product without two of the drawbacks of farming other species. Bivalves do not require feeding (Dumbauld et al. 2009), which both reduces farming costs and avoids the enrichment of the coastal marine environment with nutrients from uneaten 
food and faeces that are generated by other types of farmed marine life. Feeding as they do at the base of marine food webs, bivalves remove phytoplankton from the water and convert it to edible protein. Consequently, bivalve culture may improve water quality in bays by reducing the risk of phytoplankton overgrowth (eutrophication) that follows input of nutrients from human activities such as fertilization of farmland, or sewage disposal. However, because they compete with each other for an unenhanced natural resource (phytoplankton), over-stocking of bivalves potentially leads to decreased production, to the detriment of the entire ecosystem, as has happened with Pacific oysters in the Archachon and Marennes-Oléron regions of France (Buestel et al. 2009).

Using data collected in 1994 and 1995, a suite of studies focused on the key aspects influencing bivalve productivity in Saldanha Bay: water exchange and nitrogen flux between it and the Benguela upwelling system (Monteiro et al. 1998), phytoplankton production (Pitcher and Calder 1998), carbon flow between different trophic levels of the system (Grant et al. 1998), and fine-scale dynamics and impacts of mussel raft production (Heasman et al. 1998; Stenton-Dozey et al. 2001). The mussel production system then was raft-based. We used mussel production totals from this project, coupled with projected potential estimates from an unpublished thesis (Froget 1998) carried out under the auspices of the French Research Institute for Exploitation of the Sea (Institut français de recherche pour l'exploitation de la mer, IFREMER), to estimate whole, live, shell-on mass of bivalves that might be cultured in Saldanha Bay (Table 1) without disrupting other components of the food web of the Bay - the ecological carrying capacity for bivalve culture. This exercise suggests that in the 345 ha now allocated for bivalve culture in the Bay, Saldanha is currently capable of producing $12,470-33,253 \mathrm{t}$ of live bivalves per annum: 10.6 to 28.3 times the current production of $1,176 \mathrm{t}$ per annum (1,000 $\mathrm{t}$ of mussels and $176 \mathrm{t}$ of oysters, this study). The $37 \%$ carbon surplus (excess of primary production over consumption) at the time of the 1998 studies means that these estimates are conservative, and likely to be well within the total carrying capacity of the Bay, which is ultimately dictated by nitrate-limited primary production (Monteiro et al. 1998). Local depletion of phytoplankton such as that observed between densely-stocked mussel ropes (Heasman et al. 1998) is likely to be less for more dispersed oyster long-lines.

Multiplying the current direct employment total of the sector ( 89 jobs, including directors) by the above production factors suggest an employment potential of between 943 - and 2,518 individuals, potentially benefitting an equal number of households, and supporting a further 2,830 to 7,554 peoplebetween 4.3 and $11.4 \%$ of the total population of the greater Saldanha area (Table 1). Moreover, the Food and Agriculture Organization of the United Nations (FAO) estimates that, for every primary sector position in aquaculture, four positions are created in the secondary sector (FAO 2009: 7). Should the bivalve sector expand to include more value-added products than are currently produced, then it could possibly result in employment opportunities approaching those suggested by the FAO.

Ecological carrying capacity is thus unlikely to limit industry expansion, but we wish to attach several important caveats to our use of the 1998 Saldanha Bay project values to estimate the current ecological carrying capacity of Saldanha Bay for bivalve production. First, since 1994 and 1995 the biota, oceanography, productivity, and water circulation patterns of the Bay may well have changed - these are all determinants of nitrogen and carbon flow, hence carrying capacity. Second, mixed bivalve culture differs from the purely mussel culture that was the subject of the 1998 studies. Balancing these concerns is the fact that our estimates are conservative, limited as they are to the small fraction of the Bay area currently zoned for mariculture ( 345 ha, which equals $7.7 \%$ of the Bay's total productive area of 4,480 ha). The 1998 studies are the best published data for estimates of ecological carrying capacity of the Bay, which is currently being reassessed (G.C. Pitcher, personal communication) as part of a programme that will yield data suitable for revision of our present estimates. In future, use of approaches such as mass-balance ecosystem modelling to estimate ecosystem carrying capacity (e.g. Byron et al. 2011) are likely to refine potential production values, and are vital as the industry expands. Also needed are fine-scale spatial studies of water flow and primary and bivalve productivity in modern long-line culture systems, which are less clumped than rafts.

Caveats notwithstanding, the simple estimations above yield two insights. First, constraints to bivalve production in the bay are unlikely to be ecological, highlighting the need to assess economic and administrative constraints. Second, bivalve production in Saldanha Bay has the potential to expand sustainably by at least one order of magnitude. Its potential for job creation will expand accordingly, even if economies of scale mean that the two rates of increase are not parallel. This is an important measure of the sector's socio-economic value in the context of planned expansions of mineral ore and fossil fuel industries in the Bay.

\section{Social, economic, and policy factors influencing the sustainability and growth of small-scale mariculture}

Regardless of the geographical location or product farmed, five common factors influence the sustainability, growth and employment creation potential of mariculture ventures. Below, we combine published information about national and provincial policies relevant to mariculture in Saldanha Bay with data from the interviews we conducted to assess how these five factors currently affect the bivalve sector. All are interlinked, but some exert a largely beneficial influence whereas others present challenges to growth. 
The state

When functioning optimally, national and regional governments regulate operations and the import and export associated with mariculture, protecting the sector from user conflicts, overexpansion, and disease and other biosecurity risks such as the introduction of alien species. The state may also provide policies promoting sustainable development and local participation through, for example, creation of coastal exclusive-use mariculture zones. It may supply research funding, promote development through sponsored marketing and networking, or provide operational loans and empowerment grants (Britz et al. 2009).

A historical perspective on the development of South Africa's aquaculture policy is provided by Rouhani and Britz (2011), who highlighted the need for constructive cooperation between government and the private sector, particularly in businesses starting up. Mariculture has developed at a slower rate than in many other countries because of policy changes and the political transition. South African departments of provincial nature conservation departments changed policies relating to the stocking of exotic species in indigenous waters at the end of the 1980s/beginning of 1990s. As a result, government support was withdrawn from the aquaculture sector and an oyster hatchery in Knysna closed down. With the political transition in the mid1990s, aquaculture research and development lost government funding and policy support (Hinrichsen 2007). However, growing government interest in this sector over the past 3 to 4 years has led to constructive revisions of both legislation and policy. Notably the abalone sector, but also bivalve culture, have grown in the past decade and increasingly provide employment in coastal communities (Britz et al. 2009).

\section{General policy}

The national policies most directly relevant to aquaculture are as follows: the Policy for the Development of a Sustainable Marine Aquaculture Sector in South Africa, drawn up by the Department of Environmental Affairs and Tourism (DEA\&T) in 2007 (Republic of South Africa 2007a), and under the custodianship of DAFF. This seeks to promote the development of environmentally sustainable and internationally competitive mariculture in South Africa, requiring co-operation between the Departments of Trade and Industry (DTI), Science and Technology (DST), Agriculture, Forestry and Fisheries (DAFF) and DEA\&T itself. It stresses support of small, medium and micro enterprises (SMMEs) - all mariculture operations except abalone farms fall into this category. This policy also encompasses a Marine Aquaculture Code of Conduct. DAFF is currently finalising an Environmental Management and Monitoring
Framework for Marine Aquaculture in South Africa (Republic of South Africa 2012a, b). An Environmental Integrity Framework for Marine Aquaculture has also been published by DAFF (Republic of South Africa DAFF 2012), and the DTI has launched an Aquaculture Development and Enhancement Programme (ADEP)

The National Industrial Policy Framework (NIPF) prioritises the financial and technical support of SMMEs, together with strengthening of market opportunities (Republic of South Africa DTI 2007). However, implementation of the framework doesn't always deliver on this promise: for example, applications for support may be so complex that they require the services of specialist consultants, whose fees are only affordable by medium-sized enterprises (Britz et al. 2009).

At the provincial level, the Western Cape has made substantial recent advances through the co-ordinating efforts of the Western Cape Aquaculture Development Initiative (WCADI). The Department of Environmental Affairs and Development Planning (DEA\&DP) has published a Generic Environmental Best Practice Guideline for Aquaculture Development and Operation in the Western Cape (Hinrichsen 2007), and the Western Cape Aquaculture Implementation Plan has been finalised.

\section{Legislation}

National legislation governing farming of farmed marine organisms within South Africa, and import of live seed and spat, is currently under revision (see overview by Rana 2011). Most important are three Acts: the Marine Living Resources Act of 1998 (Republic of South Africa 1998), which was written for capture fisheries and is currently under revision by DAFF to improve its applicability to aquaculture. Second, the National Environmental Management: Biodiversity Act of 2004 (Republic of South Africa 2004) governs farming with non-native species such as all bivalves farmed in Saldanha Bay. Species status schedules for this Act, which determine its direct impact on mariculture, are also currently under review. Third, the National Environmental Management: Integrated Coastal Management Act of 2008 (Republic of South Africa 2009) focuses on management of coastal waters for environmental sustainability.

\section{Health and safety regulation}

Oysters are consumed live and raw, and mussels have a particular tendency to accumulate algal biotoxins produced during Harmful Algal Blooms (HABs; Pitcher et al. 2011). Consequently, health and hygiene standards for their culture, packaging and sale are extremely important for consumer safety. For the South African market, these are in placeregular and compulsory monitoring for heavy metals, harmful 
algal bloom biotoxins, and human pathogens such as coliform bacteria is carried out by the South African Live Molluscan Shellfish Monitoring and Control Programme (Republic of South Africa DAFF 2012b) in conjunction with municipal authorities. During our interviews, directors expressed varying opinions about the potential role of government support during harmful algal bloom closures: provision of disaster relief to terrestrial farmers after extreme weather is a parallel. Periodic closures represent loss of income that small operations find difficult to absorb.

In Walvis Bay, Namibia's Vision 2030 (Republic of Namibia 2004) together with government financial support for research and development played a decisive role in the recovery of the oyster sector following the HABs of 2008. Although nearly an entire year's crop of oysters was lost, supportive policies and subsidies for research and development helped rebuild the industry (Mapfumo 2009). This neighbouring country is a major competitor for South African oyster farmers, and is a model worth learning from.

Consequently, two of the directors we interviewed identified health certification for export as another regulatory framework crucial to the future wellbeing of the industry. In early 2012, new and stringent regulations for the import for live aquatic animals were communicated to the South African government by China, prompting transfer of state responsibility for this to the South African National Regulator for Compulsory Specifications (NRCS), in conjunction with local municipal authorities. This state of flux currently prevents direct export to the huge Chinese markets, and to the European Union: a significant bottleneck for expansion of the bivalve sector. At present, DAFF is trying to mitigate the negative impact of the transitional situation by issuing a limited number of permits for oyster export to Southeast Asian territories, such as Hong Kong.

\section{Regulatory implementation}

Although this multitude of policies aims to guide, support and co-ordinate development, the complexity of regulations leaves small-scale farmers frustrated and inhibits entry into and growth of the market. A recent countrywide survey of all aquaculture sectors revealed that excessive state regulation has led to a perception among small-scale producers that their industry is over-regulated (Britz et al. 2009): directors in our interviews reiterated this opinion. In Saldanha, bivalve farmers are currently required to obtain five permits: a mariculture permit that (most unpopularly) includes transport of their products at sea and onto the land, a local fishing vessel license for each vessel used, and a Fish Processing Establishment Permit to clean, wash, store and pack live or frozen products. Essential spat and seed importation requires a permit. Finally, farmers wishing to access global markets require export permits. Submission of applications for all these permits is time-consuming because electronic and postal submission systems are not in place, so documents must be submitted in person in Cape Town. The regulatory authority for these permits, DAFF, is currently engaged in streamlining permitting procedures, but substantive changes have yet to be experienced by the farmers.

Awareness of the need for regulation varied among our study participants: without permit restrictions, the sector poses threats to both biodiversity and itself. For example, oyster spat are imported and may carry potentially invasive alien organisms on their shells, and disease that may threaten farmed and wild oyster stocks. Nonetheless, as mentioned above, the application of legislation and policies developed for capture fisheries is inappropriate for a farming sector.

At odds with stated policy on enabling mariculture development, harbour water area leasing conditions and contracts are expensive and administered on a short-term profit-making basis that is inimical to medium and longterm development of the sector: all directors identified this as cause for great concern. In Saldanha Bay, bivalve farmers lease a portion of the marine "commons" from Transnet National Ports Authority (Portnet), a subsidiary of the parastatal organisation Transnet which is administered by the South African Department of Public Enterprises. Portnet designates water area for bivalve mariculture use, determines lease fees, and currently issues leases for a maximum of five years. Directors and state representatives variously described the rates charged by Portnet as excessive, the highest in the world, and 13 times higher than those charged in Namibia - one of the most significant factors hindering growth and preventing entry into the sector.

Harbour land leases for bivalve cleaning, wet storage and packing facilities are administered by the Department of Public Works, and several Saldanha Bay farmers currently hold leases on a month-to-month basis. Clearly, this makes capital investment in land-based infrastructure risky, and compounds the insecurity generated by concerns over water area tenure and expense.

\section{The market}

The second factor, market demand, is possibly the most obvious of the five influences on sustainability. Market demands fluctuate and without import restrictions, local markets may be flooded with under-priced imports. Expansion of employment capacity in bivalve mariculture is linked to the industry's ability to grow along with its local and international markets by increasing production of live and processed products, obtaining health clearance, and national and international marketing. An exciting recent development is the 2012 preparation by WCADI of a draft Western Cape Aquaculture Market 
Analysis and Development Programme/Strategy, which seeks to co-ordinate efforts to develop both local and international markets. Dialogue about this issue is increasing, particularly in the Western Cape.

Between 2005 and 2008, the value of South Africa's oyster production increased by $42 \%$, contributing R 8.5 million to the total aquaculture sector in 2008 . Over the same period, mussel production increased by $43 \%$ to R6 million (Britz et al. 2009: 20 ). More recently, annual production of oysters and mussels in 2010 were R14.4 and R9.1 million respectively, making these the second and third most valuable mariculture products, with the R355 million abalone sector dominating (Republic of South Africa 2011). The oyster sector has shown consistent production and market growth (Britz et al. 2009). A $30 \%$ global deficit in mussel products suggests that these also have good growth potential (Karaan 2009). One producer commented that after 20 years, South African bivalve culture is finally beginning to make some "real progress", especially in terms of value-added and export product development (Britz et al. 2009).

There is great potential for South African oysters on the international market, where the demand for seafood is increasing. South Africa's natural environment, particularly the rich upwelling system on the West Coast, provides a competitive edge over many Asian countries (Karaan 2009), but one of the current challenges to export is South Africa's lack of international standards of health certification, discussed in the previous section.

No mussel products are exported from South Africa, as production does not fill the local market's demand. The large scale of production and the strong economies of leading mariculture producers in competing countries also pose challenges to South Africa's mussel export industry. In contrast, South African oyster production has the advantage that when northern countries are experiencing summer mortality, South African oysters are in peak condition in the middle of the southern hemisphere winter.

According to Saldanha mussel farm directors, South Africans prefer locally produced to imported mussels: this demand should translate directly into economic gains. However, local mussel products are out-sold by under-priced inferior imported mussels from countries that subsidise mussel culture, forcing local producers to cut their profit margins in order to compete. A disturbing parallel is the 2004 collapse of Amatikulu Prawns in KwaZulu-Natal, South Africa, ${ }^{1}$ which was directly related to the dumping of surplus prawns from biannual Indian harvests on the South African market. Slower prawn growth in South Africa allowed only one harvest per year, and the suddenness of the loss of market share left no

\footnotetext{
${ }^{1}$ Amatikulu Prawns was established in 1981. After initial pilot tests, the farm expanded its commercial production in 1997. However, due to market slumps and dumping of prawn imports on the South African market, the farm became financially unviable and closed down in 2004.
}

time for technology-driven increases in local production (Evans 2009; Enslin 2004; Sadek et al. 2002).

Depression of product values by such competition, in addition to high running costs and a costly regulatory environment, prevent oyster and mussel farms from accumulating sufficient capital to reinvest in expansion, production and renewal. Thus, most of the larger farms in the Bay have reached a 'ceiling' in their economies of scale that they are unable to progress beyond without a substantial financial injection. These farms are under constant financial pressure and their directors are uneasy about the sustainability of the bivalve mariculture sector under such conditions. Expanding the mariculture farms would not only allow more effective competition for local markets, but also on the international arena.

The two directors whose companies supply oysters to the Asian market claimed that the United Arab Emirates (UAE) and the Southern African Development Community (SADC) countries wish to purchase more mussels and oysters from South Africa, as it is cheaper for them to import from here than from the Northern Hemisphere. These markets have substantial growth potential, and accessing them is central to the continued growth of the sector.

\section{Funding}

Access to adequate finance for research and development, and capital investment, was one of the highest priorities listed in Britz et al.'s (2009) benchmarking survey of South African aquaculture. The development of oyster and mussel culture in South Africa has hitherto been dependent on private-sector finances (Haupt et al. 2010). Investors are difficult to source, yet three of the five farms in our study rely solely on private sector funding, with no state support. This has limited the sector's expansion, and may reflect the fact that, although financial support of SMMEs is a key component of the NIPF, application for these funds is complex and difficult. Moreover, economies of scale and operational pressures often make it extremely difficult for SMMEs to generate enough profit to expand, increase efficiency, and upgrade infrastructure in order to remain competitive on national and international markets. Capital investment or low-interest loans are a mechanism through which provincial and national government might help small businesses grow into significant employers. Respondents to industry surveys in 2008 recommended "a governmentsupported aquaculture loan fund" (Britz et al. 2009). In a case study of an empowerment mussel business in Saldanha, Botes et al. (2006) suggested that regional government intercede in the development process of SMMEs. Once more, a positive example is set by Namibia: state funding enabled successful oyster farmers from Walvis Bay to attend international conferences on oyster production and marketing (Mapfumo 2009). 
Emergency aid in the event of HAB-induced closures is a theoretical example of a potential support measure. The majority of directors in our survey described how the continual financial strain of biotoxin monitoring, compounded by market fluctuations, exhausts capital and prevents reinvestment. The considerable expenses for the mandatory health monitoring (described above), combined with profit losses during intermittent HAB closures, place sufficient financial strain on two of the farms we surveyed to cause suspension of employee salaries during closures. Two directors suggested that the state subsidise monitoring costs (and possibly, less realistically, employee salaries during temporary closures).

Based on our assessment below ("The Local Population"), the bivalve sector complies with funding criteria for state support, so increased confidence and state investment in bivalve aquaculture would be justified. However, because bivalve aquaculture is considered a high risk enterprise, insurance is unrealistic. Thus, temporary closures, or worse, collapse, are continuing risks to sustainability of the sector.

\section{The environment}

The fourth factor governing mariculture economics is environmental variability, both seasonal and unpredictable. The health of bivalves and their consumers is subject to both natural variation in toxic or pathological organisms, and potentially polluting large industries and coastal urban developments. Continuous environmental monitoring and conservation of the marine environment are essential prerequisites to production of healthy and edible mussels and oysters.

State intervention can improve a sector's resilience to environmental variability. In Grand Manan, the provincial government responded rapidly to the outbreak of Infectious Salmon Anaemia (ISA), implementing a twoyear moratorium on the development of any new sites, the culling of infected fish and a policy stipulating uniform grow-out cycles per site (McGeachy and Moore 2003; Marshall 2001, 2005). This response saved the sector from collapse.

In Saldanha, the natural environment is one of the sector's greatest assets: both the quality of the water and the relatively sheltered topology are optimal for bivalve production. For all its anthropogenic influences, natural processes such as the Benguela upwelling system and circulation of upwelled water into the Bay, still contribute to a particularly productive environment. Although heavy metal contamination levels require monitoring, the levels of nutrients, chlorophyll, oxygen and salinity, are healthy particularly in Big Bay. Small Bay, the section enclosed by the ore jetty and the Marcus Island Causeway, is more altered (Clark et al. 2009). Confirming this, Saldanha Bay exhibits some of the fastest bivalve growth rates in the world (Haupt et al. 2010; Karaan 2009; Pieterse et al. 2012). Nonetheless, maintaining the quality of the water is essential for continued sustainability of the bivalve sector, particularly in view of the possibility of large ore transport, oil storage and gas transport facilities in the Bay. Further dredging of the bay would be potentially disastrous, increasing sediment loads in the water and moving settled pollutants into the water column. Filter-feeding mussels and oysters are extremely vulnerable to siltation, which impairs their ability to both exchange gases and feed.

As mentioned above in the section on legislation, Harmful Algal Blooms (HABs or "red tides") are an unpredicatable feature of South Africa's West Coast, including Saldanha Bay. Although these usually do not harm oysters and mussels, biotoxins secreted by phytoplankton during the blooms are absorbed into the bivalves' flesh and may be harmful or lethal to humans if eaten. HABs in Saldanha in 2009, 2010 and 2011 necessitated temporary closures of all farms whose products showed levels above safety thresholds, with complete income losses for those periods. In extreme cases such as those in Walvis Bay in 2008, rapidly increasing plankton populations deplete oxygen available to other marine organisms and combine other factors to kill stock.

Although HABs are a natural phenomenon, they may be exacerbated by anthropogenic influences such as fish processing, sewage and storm water influx, or the re-suspension of sediment from underwater blasting and dredging during construction and maintenance of iron ore facilities (Clark et al. 2009; Probyn et al. 2001). The greatest current threat to water quality in Saldanha Bay is sewage discharge (Clark et al. 2009).

The marine commons in Saldanha Bay is utilised by commercial and recreational interest groups. Common challenges arise from recreational fishermen, whose motorboat propellers damage partially-submerged long-lines. Theft of sometimes large quantities of mussels for bait, accompanied by occasional cutting of mussel ropes, is a cost for mussel farmers. One director estimated the loss of stock to theft and vandalism to be R200 000 per year. Cases of intra-sector theft were also mentioned to occur on oyster farms. The director stated that such incidences could be followed up, as the sector is still small and the farm employees know each other.

Commercial fishmeal production was mentioned by one director as a problem in the recent past: compliance of fish processing plants with environmental regulations is perceived as a problem. Although this is currently not a risk in Small Bay, where recent closure of a fishmeal plant led to an immediate improvement in water quality, such plants might reopen in future. Several directors are concerned about the proposed development of mineral ore and fossil fuel (oil and natural gas) storage and harbour facilities. 
Awareness of the risks of climate change and ocean acidification was limited to two directors.

\section{The local population}

The fifth factor that is critical to the success of the mariculture sector is the availability of the necessary skills and labour within the local community. The bivalve sector runs 40 to 50-hour weeks, plus overtime during peak market demands in December and January, requiring a labour force that lives close by. Economic need in the local community is manifest: the population of the town of Saldanha has grown by $29 \%$ since 2001: from 21,640 in 2001 to over 28,000 in 2010 (Clarke et al. 2009; Saldanha Bay Municipality 2007). Almost half (48\%) of the population has some form of secondary education and grade 12 (matriculants) make up $22 \%$ of the population. However, an equal fraction (22\%) of residents older than 14 years are functionally illiterate, and a mere $8 \%$ of the population has a higher education qualification (Saldanha Bay Municipality 2007: 7). Most households are poor: $65 \%$ live on a monthly income of R3 200 or less, $22 \%$ of these falling below R800 per month. In Saldanha's informal settlement, Middlepos, $41 \%$ of households have an income of less than R500 per month and as many as $55 \%$ of inhabitants were unemployed (Vorster and Heinecken 2009). Saldanha's unemployment rate far exceeds the South African municipal average (25\% in 2011, StatsSA 2011). In addition to the downscaling of the fisheries, a major contributing factor to rising unemployment is the influx of job seekers from elsewhere in South Africa.

In this context, state representatives explained to us that the South African government has recognised the bivalve culture sector's socio-economic potential, and is willing to invest in companies that can demonstrate their ability to create jobs, develop viable ventures, create sustainable partnerships and promote Black Economic Empowerment (BEE). The bivalve mariculture sector has the potential to qualify for all of the funding criteria.

The first criterion (job creation) is fulfilled as bivalve aquaculture offers the highest employment per unit of investment of any of South Africa's aquaculture sectors. Oyster culture is one of the most labour intensive of all aquaculture industries (Britz et al. 2009) and, according to one of the state representatives we interviewed, mussel culture employs more people per unit of investment than South Africa's leading aquaculture sector, abalone.

Secondly, the bivalve mariculture sector in Saldanha is economically viable because very little additional investment in infrastructure is needed to accompany an expanding sector. Transport, communication and basic services are well established because Saldanha supports large-scale international mineral ore and fossil fuel industries.
Third, Saldanha's bivalve sector has demonstrated that both oyster and mussel farming provide a platform to develop partnerships. For example, one of the oyster farms in Saldanha Bay practices employee shareholding and has already received state funding for this. The large mussel farm is in partnership with a $100 \%$ empowerment scheme, with six black shareholders owning nine mussel rafts (Botes et al. 2006). None of these shareholders possesses a matric. This Broad-Based Black Economic Empowerment (BBBEE) partnership has also qualified for Western Cape Department of Agriculture funding. In general, bivalve mariculture farms in Saldanha demonstrate considerable potential for internal BBBEE. Three out of the five have a high BBBEE rating. Two of these farms are $66 \%$ black owned: one due to the shareholder model described above and the other with two of the three directors who are black. Four of the seven supervisors across the five companies are black, as is one qualified skipper. Lack of a formal education is not a barrier to advancement within the sector: our surveys show that $75 \%$ (both genders combined) of the workforce employed by the bivalve sector in Saldanha is educated to Grade 9 level or less, and a further $21 \%$ of factory employees had passed matric (Grade 12). Individuals without a Grade 12 pass have limited alternative livelihood options, but their low education level need not be a barrier to entry into and empowerment within this particular industry.

The local community both influences and benefits from sustainable development of an aquaculture sector. Because mariculture generates small profits per unit production, is highly labour-intensive and requires unpredictable and often exceptionally long work-hours, particularly during peak seasons, its sustainable development requires a local community with a high proportion of unskilled and semi-skilled labourers living relatively close to their place of employment. This workforce also needs to be flexible in their approach to work-hours (and thereby income), and highly dependable.

Skills such as boat-handling, commercial SCUBA diving, mechanical repairs (pump and boat engine) and construction must also be sourced locally. Saldanha is historically a fishing town, and such skills are available, having been developed to service the industry now being replaced by mariculture.

\section{Conclusions}

Government has recognised the employment potential of South Africa's mariculture sector. Our study suggests that Saldanha's bivalve mariculture sector is sustainable, but that its development, hence the growth of its employment capacity, is limited by perceived and actual difficulties in implementation of state policies, by access to the international market, and by a lack of funding for development. 
Although South African government policies ostensibly support both mariculture and small businesses, we found that directors experience the regulatory environment as more appropriate for a larger-scale industry, thus too restrictive and expensive for the SMMEs currently dominating the bivalve mariculture sector in Saldanha Bay. Exceptionally high water area lease fees charged by Portnet (13 times those in Namibia, a neighbouring competitor) were identified as another constraint. In summary, regulatory constraints and economies of scale, coupled with a lack of surety arising from the nature of marine water leaseholds, means that bivalve farms in Saldanha cannot generate sufficient capital to expand, nor can they easily secure loans from formal institutions. Thus, despite its stated objectives of supporting the sector, state implementation of those objectives still requires improvement.

Both the South African and international markets for oyster and mussel products are good despite the recent economic recession, although subsidised imports of mussels compete with local products to reduce profits within this sub-sector. The high quality of South African bivalves bodes well for the export potential of the industry. Funding for the capital outlays required to increase production and improve economies of scale would improve competitiveness on local and international markets, highlighting the second constraint identified in our study: funding. Private investment and state assistance in the form of development grants and assistance during biotoxin closures, would allow this sector to expand. Currently, constant financial strain arising from the costly regulatory environment combines with periodic closures to reduce profits and hinder reinvestment within the industry.

The natural environment is one of the sector's greatest assets, contributing to premium quality products and extremely rapid organism growth. Our estimates suggest that bivalve mariculture in Saldanha Bay has the potential to expand by 10 to 28 times. However, maintaining water quality and ecosystem health are essential to the sector's development. Risks of algal blooms are increased by fish processing, sewage, storm water or the re-suspension of sediment from underwater blasting and dredging. Consequently, environmental regulation of other industries using Saldanha Bay and the sewage and storm water systems of the Saldanha Municipality are crucial to the continued growth of the industry, hence fulfilment of its socio-economic potential. Harbour development for large ore- and fossil fuel-related industries is a real future threat.

Finally, the local community is an asset to the sector's expansion in Saldanha. An experienced pool of directors, a decades-long history of refinement of culture techniques for local conditions, and the sector's relatively low educational requirements for factory staff combine to enhance its potential for socio-economic upliftment of needy West Coast communities. Bivalve mariculture is low-impact relative to other industries in the area, so its expansion would be environmentally sustainable.

Measured against the five key influences that affect the potential for sustainable expansion, the sector has potential to expand by at least an order of magnitude, directly providing employment for between 940 and 2,500 individuals, potentially supporting 3,700 to 10,000 people. Substantial recent changes to legislative and regulatory frameworks bode well for the future of mariculture in South Africa.

Acknowledgements We are most grateful to the following people for their valuable time and insights: Peter Britz, Joseph and Gloria Dayimani, Wilhelm Herbst, Nelia Lochner, Vos Pienaar, Kevin Ruck, and Antonio Tonin. This research was supported by a grant from Stellenbosch University through the West Coast Food Security research project bursary, and by a grant from the Marine Living Resources Fund of the Department of Agriculture, Forestry and Fisheries.

Open Access This article is distributed under the terms of the Creative Commons Attribution License which permits any use, distribution, and reproduction in any medium, provided the original author(s) and the source are credited.

\section{Appendix A: Semi-structured interview schedule for state representatives}

STATE REPRESENTATIVES: SEMI-STRUCTURED INTERVIEW

Representative Number

Date 
INTRODUCTION: Hello, my name is David Olivier. I am currently studying for my Master's degree in Sociology at Stellenbosch University. My thesis investigates the potential for Saldanha's mariculture industry to expand and generate local employment. The information that you provide through this interview will be used along with the information from others to inform my thesis question. Your identity will be kept anonymous and anything that you choose to say will be treated with total confidentiality. You may choose to skip any question you do not want to answer and you can call the interview to a close at any time you want, if you feel the need. The questions are general questions that aim to generate discussion on South Africa's mariculture industry. Would you like to continue?

\section{SCHEDULE:}

- THE STATE has recognised the potential for freshwater and marine aquaculture to provide socio-economic development and food security, but what is it doing at the moment to develop a robust and expanding industry?

- On a macro level?

Policies

Grants

Information

Permitting

Access of small businesses

Access to local and international markets

- On a micro level (specifically Saldanha)?

Zoned areas (how much space is available)

Assistance with water quality monitoring

Infrastructure development

- THE LOCAL COMMUNITY may benefit from the availability of more low-skill positions becoming available with an expanding mariculture industry, but what could be done to ensure that the locally unemployed do not miss out on this opportunity or end up worse off for this as has happened in other cases?

- Influx of in-migration as work opportunities open up

- User-group conflicts

Conflict between retrenched 'local' fishers and newly arrived job-seekers from elsewhere

Port expansion; industrial/residential development ; fish-processing factories versus water quality

- THE MARKET for freshwater and marine aquaculture products appears to be expanding, but not without significant international competition.

- Is the space available in Saldanha for mariculture sufficient to support the demands of an international market?
- Is the current infrastructure in Saldanha sufficient to support the demands of an international market?

- FUNDING has been identified as one of the major limiting factors to the expansion of South Africa's mariculture sector; most of the growth thus far has been sustained by private sector funding. Stakeholders in the aquaculture industry suggested a "government supported aquaculture loan fund" (Britz et al. 2009) being made available.

- What is the government's approach to the provision of funding for small-scale entry to the market? (small-scale operators reported not being able to benefit from the SMEDP)

- What is the government's approach to financially protecting the mariculture industry from shocks such as crop failure or a market drop?

- Could the mariculture industry benefit from the funding model for rural entrepreneurs mentioned in the 2010 Budget Vote Speech that proposes to provide funding for farmers, foresters and fishers in the 2011/12 financial year? (Joemat-Pettersson 2010)

- THE ENVIRONMENT plays a crucial role in the sustainability of local mariculture industries. The Benguela upwelling provides Saldanha Bay with premium quality water for oyster and mussel farming, but what future risks are there from ongoing development around Saldanha Bay? What is being done to monitor and avoid shocks from the environment?

- Shipping

Heavy metals, oil spills

- Fish-processing waste

- Sewage

Leaks and processed waste

- Storm water

- The natural environment

Toxic algal blooms

Parasites and disease

- CONCLUDING QUESTION: My knowledge of Saldanha's mariculture industry is still very limited. Is there anything that you feel is important that $I$ have not addressed during this interview?

Thank you for your participation. The information you have provided for the study will be used along with that from other interviews to address the question of the sustainability and expansion of a mariculture industry in Saldanha Bay. Everything that you have said will be treated with total confidentiality. Your identity will be kept anonymous at all times. 


\section{MARICULTURE DIRETORS: SEMI-STRUCTURED INTERVIEW}

Farm Number

Date

INTRODUCTION: Hello, my name is David Olivier. I am currently studying for my Master's degree in Sociology at Stellenbosch University. My thesis investigates the potential for Saldanha's mariculture industry to expand and create local employment. The information that you provide through this interview will be used along with the information from others to inform my thesis question. Your identity will be kept anonymous and anything that you choose to say will be treated with total confidentiality. You may choose to skip any question you do not want to answer and you can call the interview to a close at anytime you want, if you feel the need. The questions are general questions that aim to generate discussion on your experiences of South Africa's mariculture industry. Would you like to continue?

\section{SCHEDULE:}

- THE STATE, according to the Aquaculture Benchmarking Survey (Britz et al. 2009), has been unsupportive towards the entry of small-scale businesses into aquaculture in the past. Since the survey, the Department of Environmental Affairs and Development Planning (DEA\&DP) of the Provincial Government of the Western Cape has published guidelines for starting an aquaculture business in which they express their interest in becoming a stakeholder in the local aquaculture industry. Other developments have also taken place to suggest that the government is becoming more supportive of South Africa's aquaculture industry.

- What would you say are some of the most important contributions the state can make towards the development of South Africa's mariculture industry?

Do you see this coming to pass in the near future?

- Have you experienced any changes in the past year or two that may suggest that the state is becoming more supportive of the aquaculture industry in SA?

\section{- THE LOCAL COMMUNITY}

- Projecting the industry's employment potential depends on knowing the annual/monthly production of oysters (or mussels).

- In tons fresh weight, and/or in numbers of oysters/mussels sold per month and size, what was the production output for the last year?

- The local community may benefit from an expanding industry, but the majority of unemployed individuals could miss out on the opportunity if specific skills sets are required that they do not have and if an increased in-migration quickly saturates the demand for labour positions.

- What positions are there on your mussel/oyster farm? What are the corresponding skills requirements? May the job be filled by either gender or both? How many people are employed in these positions? [use graph below]

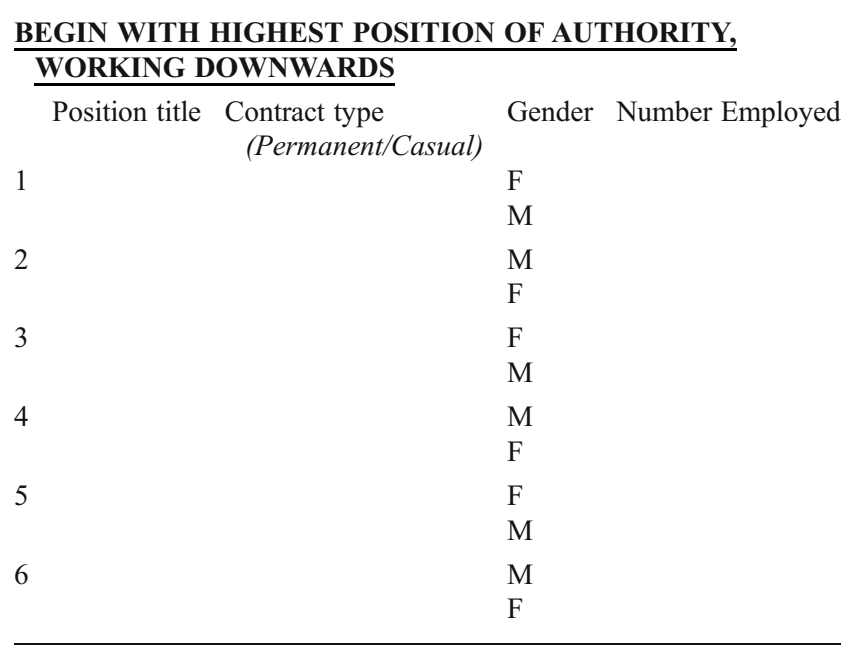

What do you look for before employing someone for a labour position?

- User-group conflict 
Are there any users of the bay that you or your employees have conflicting interests with besides the competition from other mariculture farmers? [such as shipping, fishing companies, recreational users etc...]

- What has been the cause for this conflict in interest? Has there been any conflict in interest with other mariculture farmers?

- What has been the cause for this conflict in interest? Has conflict in interest ever led to direct action being taken, either formally or informally, against the conflicting party? Please explain.

What measures are there to limit or mediate user conflict?

- Has your business experienced any incidents of crime in the past 12 months?

What was the nature of the crime?

Have you felt that the sustainability of your business is threatened by crime?

- THE MARKET for mariculture products in South Africa is growing. However, major competition exists on the international market.

- Do you currently supply an international market, or if not, do you plan to expand to do so?

What have been, or are, some major limitations to doing so?

What have you done, or could you do, to overcome these limitations?

What strengths does your business have that make it competitive on the international market?

Which products do you, or do you plan to, sell to the international market? [List in rank order of value, with 1 being highest in value]

- The South African market

What are some of the limitations to your expansion on the South African market?
What can be done to overcome these limitations?

- FUNDING/ ACCESS TO FINANCE was named as one of the highest priorities for the expansion of South Africa's aquaculture industry in Britz et al.'s (2009) Aquaculture Benchmarking Survey.

- Has the expansion of your business been limited by inadequate funding?

- Have you received any financial support from the government?

If so, what qualified you?

- What have been, in order of importance, the sources of funding that your business has used?

- What sources of insurance do you have against sudden shocks to your business?

- THE ENVIRONMENT plays a crucial role in the sustainability of local mariculture industries.

- What environmental influences have threatened production or have brought on unexpected expenses in your experience?

What can be done to address or monitor such influences in future?

- CONCLUDING QUESTION: My knowledge of Saldanha's mariculture industry is still very limited. Is there anything that you feel is important that $I$ have not addressed during this interview?

Thank you for your participation. The information you have provided for the study will be used along with that from other interviews to address the question of the sustainability and expansion of a mariculture industry in Saldanha Bay. Everything that you have said will be treated with total confidentiality. Your identity will be kept anonymous at all times.

\section{MARICULTURE EMPLOYEES, SALDANHA, SOUTH AFRICA: SEMI-} STRUCTURED INTERVIEW

Farm Number

Date 
INTRODUCTION: Hello, my name is David Olivier. I am currently studying for my Master's degree in Sociology at Stellenbosch University. My thesis investigates the potential for Saldanha's mariculture industry to expand and create local employment. The information that you provide through this interview will be used along with the information from other interviews to inform my thesis question. Your identity will be kept anonymous and anything that you choose to say will be treated with total confidentiality. You may choose to skip any question you do not want to answer and you can call the interview to a close at anytime you want, if you feel the need. The questions are general questions that aim to generate discussion on your experiences of South Africa's mariculture industry. Would you like to continue?

\begin{tabular}{|c|c|c|c|c|c|c|}
\hline Employee & $\begin{array}{l}\text { What is } \\
\text { your } \\
\text { role } \\
\text { at } \\
\text { work? }\end{array}$ & \multicolumn{2}{|c|}{$\begin{array}{l}\begin{array}{l}\text { Size of } \\
\text { household }\end{array} \\
\text { [Number } \\
\text { of } \\
\text { people] }\end{array}$} & $\begin{array}{l}\text { How many } \\
\text { people } \\
\text { over } \\
16 \text { and } \\
\text { under } \\
65 ?\end{array}$ & \multicolumn{2}{|c|}{$\begin{array}{l}\text { For how many } \\
\text { years have } \\
\text { you been living } \\
\text { in Saldanha? } \\
\text { [Number of } \\
\text { years] }\end{array}$} \\
\hline \multicolumn{7}{|l|}{1} \\
\hline \multicolumn{7}{|l|}{2} \\
\hline \multicolumn{7}{|l|}{3} \\
\hline \multicolumn{7}{|l|}{4} \\
\hline \multicolumn{7}{|l|}{5} \\
\hline \multicolumn{7}{|l|}{6} \\
\hline \multicolumn{7}{|l|}{7} \\
\hline \multicolumn{7}{|l|}{8} \\
\hline \multicolumn{7}{|l|}{9} \\
\hline Employee & $\begin{array}{r}\text { Highest } \\
\text { Comp }\end{array}$ & $\begin{array}{l}\text { rrade } \\
\text { ted? }\end{array}$ & $\begin{array}{l}\text { Have } \\
\text { any } \\
{[\mathrm{Su}} \\
\text { cou } \\
\text { or } 1 \\
\text { wh }\end{array}$ & $\begin{array}{l}\text { you receivec } \\
\text { other traini } \\
\text { ch as practica } \\
\text { rses, qualifica } \\
\text { ermits] If 'ye } \\
\text { t? }\end{array}$ & $\begin{array}{l}\text { g? } \\
\text { tions } \\
\text { s' }\end{array}$ & $\begin{array}{c}\text { Hours per } \\
\text { week? }\end{array}$ \\
\hline \multicolumn{7}{|c|}{ 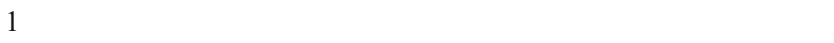 } \\
\hline \multicolumn{7}{|l|}{2} \\
\hline \multicolumn{7}{|l|}{3} \\
\hline \multicolumn{7}{|l|}{4} \\
\hline \multicolumn{7}{|l|}{5} \\
\hline \multicolumn{7}{|l|}{6} \\
\hline \multicolumn{7}{|l|}{7} \\
\hline \multicolumn{7}{|l|}{8} \\
\hline 9 & & & & & & \\
\hline
\end{tabular}

\begin{tabular}{lll}
\hline Employee & $\begin{array}{c}\text { How did you find } \\
\text { out about this } \\
\text { job? }\end{array}$ & $\begin{array}{c}\text { How many total years } \\
\text { of experience do you } \\
\text { have working on oyster } \\
\text { and mussel farms? }\end{array}$ \\
1 & \\
2 & \\
3 & \\
4 & \\
5 & \\
6 & \\
7 & \\
8 & \\
9 & \\
\hline
\end{tabular}

\begin{tabular}{llll}
\hline Employee & $\begin{array}{l}\text { What other } \\
\text { sources of } \\
\text { income are } \\
\text { there for your } \\
\text { household? }\end{array}$ & $\begin{array}{l}\text { How much } \\
\text { does this job } \\
\text { contribute to } \\
\text { the household } \\
\text { income? } \\
\text { [Percentage] }\end{array}$ & $\begin{array}{l}\text { Is there anything } \\
\text { that I have not } \\
\text { thought of that } \\
\text { you think would } \\
\text { be important } \\
\text { for my } \\
\text { research? }\end{array}$ \\
1 & & \\
2 & & \\
3 & & \\
4 & & \\
5 & & \\
7 & & \\
8 & & \\
9
\end{tabular}

Thank you for your participation. The information you have provided for the study will be used along with that from other interviews to address the question of the sustainability and expansion of a mariculture industry in Saldanha Bay. Everything that you have said will be treated with total confidentiality. Your identity will be kept anonymous at all times.

\section{References}

Botes, L., Thompson, G., \& Louw, R. (2006). Transformation in the aquaculture industry: two case studies investigating empowerment and enterprise development. A report for the Aquaculture Institute of South Africa. [Online]. http//www.aasa-aqua.co.za/ site/wp-content/uploads/2010/10/AISACaseStudies2006.pdf [2011, August 26].

Britz, P.J. (2007). A study on the status of aquaculture production and trade in South Africa. Volume 2: Growth potential of the South 
African aquaculture industry and recommendations for sector development. Report for the Department of Trade and Industry produced by Enviro-Fish Africa (Pty.) Ltd. 24p.

Britz, P. J., Lee, B., \& Botes, L. (2009). AISA 2009 aquaculture benchmarking survey: Primary production and markets. Report for the Aquaculture Institute of South Africa and Swiss Contact, produced by Enviro-Fish Africa (Pty.) Ltd.

Buestel, D., Ropert, M., Prou, J., \& Goulletquer, P. (2009). History, status and future of oyster culture in France. Journal of Shellfish Research, 28, 813-820.

Byron, C., Link, J., Costa-Pierce, B., \& Bengtson, D. (2011). Modeling ecological carrying capacity of shellfish aquaculture in highly flushed temperate lagoons. Aquaculture, 314, 87-99.

Clark, B. M., Orr, K., Hutchings, K., Angel, A., \& Turpie, J. (2009). State of the Bay 2008: Saldanha Bay and Langebaan Lagoon. Technical report prepared for Saldanha Bay Water Quality Trust. [Online]. http://www.capebiosphere.co.za/images/biosphere/ research/bayreport2008.pdf [2010, November 15].

Costa-Pierce, B. A. (2008). Epilogue: Aquaculture, innovation and social transformation. In K. Culver \& D. Castle (Eds.), Aquaculture, innovation and social transformation (pp. 1-11). New York: Springer.

Department of Agriculture, Forestry and Fisheries (2012). Summary of the environmental integrity framework for marine aquaculture. Report for the Directorate: Sustainable Aquaculture Management, DAFF, produced by EnvrioFish Africa (Pty.)Ltd and revised by AquacEco.

Dumbauld, B. R., Ruesink, J. L., \& Rumrill, S. S. (2009). The ecological role of bivalve shellfish aquaculture in the estuarine environment: a review with application to oyster and clam culture in West Coast (USA) estuaries. Aquaculture, 290, 196-223.

Enslin, S. (2004). Amatikulu Prawns woos investors [Online]. Gippsland Aquaculture Industry Network Inc. http://www.growfish.co$\mathrm{m} . \mathrm{au} /$ content.asp? contentid=1544 [2010, September 30].

Evans, L. (2009). Case study: the rise and demise of the commercial shrimp farm, Amatikulu Prawns (Pty) Ltd. 1989 to 2004 (KwaZulu-Natal, South Africa). Aquaculture Compendium [Online]. https://aquaculturecompendium.wiki.zoho.com/ Rise-and-demise-of-a-commercial-shrimp-farm-in-SouthAfrica.html [2010, September 30].

FAO. (2009). The state of world fisheries and aquaculture 2008. Rome: Food and Agricultural Organization of the United Nations.

Froget, L. (1998). Contribution to the development of mariculture in South Africa: Analysis of the potentiality of development of mussel farming and the feasibility of sea trout farming. Unpublished thesis (Diploma Agricultural Engineer), Institut National Agronomique Paris-Grignon, France.

Grant, J., Stenton-Dozey, J., Monteiro, G. P., \& Heasman, K. (1998). Shellfish culture in the Benguela system: a carbon budget of Saldanha Bay for raft culture of Mytilus galloprovincialis. Journal of Shellfish Research, 17(1), 41-49.

Haupt, T. M., Griffiths, C. L., Robinson, T. B., Tonin, A. F. G., \& De Bruyn, P. A. (2010). The history and status of oyster exploitation and culture in South Africa. Journal of Shellfish Research, 29(1), $151-159$.

Heasman, K. G., Pitcher, G. C., McQuaid, C. D., \& Hecht, T. (1998). Shellfish mariculture in the Benguela System: raft culture of Mytilus galloprovincialis and the effect of rope spacing on food extraction, growth rate, production, and condition of mussels. Journal of Shellfish Research, 17(1), 33-39.

Hinrichsen, E. (2007). Generic environmental best practice guideline for aquaculture development and operation in the Western Cape:
Edition 1. Division of Aquaculture, Stellenbosch University Report. Cape Town: Department of Environmental Affairs and Development Planning, Provincial Government of the Western Cape.

Joemat-Pettersson, T. (2010). Budget vote speech [Online]. http:// www.info.gov.za/speeches/2010/10041316051002.htm [2010, November 17].

Karaan, A. S. M. (2009). A transaction-cost approach to enterprise modelling and coordination between small growers and a large firm: The case of mussel mariculture in South Africa. In J. F. Kirsten, A. R. Dorward, C. Poulton, \& N. Vink (Eds.), Institutional economics perspectives on African agricultural development (pp. 245-256). Washington, D. C.: International Food Policy Research Institute.

Mapfumo, B. (2009). History and development of shellfish cultivation in Walvis Bay, Namibia. Unpublished report completed for SARNISSA (Sustainable Aquaculture Research Networks in Sub Saharan Africa), Namibia.

Marshall, J. (2001). Landlords, leaseholders and sweat equity: changing property regimes in aquaculture. Marine Policy, 25(5), 335352.

Marshall, J. (2005). Global markets, local foods: the paradoxes of aquaculture. In S. J. Essex, A. W. Gilg, R. B. Yarwood, J. Smithers, \& R. Wilson (Eds.), Rural change and sustainability (pp. 68-84). Wallingford: CABI Publishing.

McGeachy, S. M., \& Moore, M. J. (2003). Infectious salmon anemia in New Brunswick: an historical perspective and update on control and management practices (1997-2002). In O. Miller, R. C. Cipriano (eds.), International response to infectious salmon anemia: Prevention, control, and eradication. New Orleans, LA: Technical Bulletin 1902: 145-154.

Monteiro, P. M. S., Spolander, B., Brundrit, G. B., \& Nelson, G. (1998). Shellfish mariculture in the Benguela System: estimates of nitrogen-driven new production in Saldanha Bay using two physical models. Journal of Shellfish Research, 17(1), 3-13.

Naylor, R. L., Goldburg, R. J., Primavera, J. H., Kautsky, N., Beveridge, M. C. M., Clay, J., et al. (2000). Effect of aquaculture on world fish supplies. Nature, 405, 1017-1024.

Pieterse, A., Pitcher, G., Naidoo, P., \& Jackson, S. (2012). Growth and condition of the Pacific oyster Crassostrea gigas at three environmentally distinct South African oyster farms. Journal of Shellfish Research, 31(4), 1-16.

Pitcher, G. C., \& Calder, D. (1998). Shellfish mariculture in the Benguela system: phytoplankton and the availability of food for commercial mussel farms in Saldanha Bay, South Africa. Journal of Shellfish Research, 17(1), 15-24.

Pitcher, G. C., Krock, B., \& Cembella, A. D. (2011). Accumulation of diarrhetic shellfish poisoning toxins in the oyster Crassostrea gigas and the mussel Choromytilus meridionalis in the southern Benguela ecosystem. African Journal of Marine Science, 33(2), 273-281.

Probyn, T., Pitcher, G., Pienaar, R., \& Nuzzi, R. (2001). Brown tides and mariculture in Saldanha Bay, South Africa. Marine Pollution Bulletin, 42(5), 405-408.

Rana, K. (2011). Critical review and analysis of the current aquaculture regulatory framework in the Republic of South Africa in relation to international benchmarks. Report for Western Cape Government, Economic Development and Tourism.

Republic of Namibia (2004). Vision 2030. [Online]. Available: http:// www.npc.gov.na/vision/pdfs/Chapter_5.pdf [2010, September 15].

Republic of South Africa (1998). Marine Living Resources Act 18 of 1998. South African Government Gazette Vol. 395, No. 1893027 May 1998. 
Republic of South Africa (2004). National Environmental Management: Biodiversity Act 10 of 2004. South African Government Gazette Vol. 467, No. 26436, 7 June 2004.

Republic of South Africa (2009). National Environmental Management: Integrated Coastal Management Act 24 of 2008. Government Gazette Vol. 524, No. 3188411 February 2009.

Republic of South Africa, Department of Agriculture, Forestry and Fisheries (2011). Aquaculture annual report 2011. Chief Directorate: Aquaculture and Economic Development, Fisheries Branch, Department of Agriculture, Forestry and Fisheries, Cape Town, South Africa.

Republic of South Africa, Department of Agriculture, Forestry and Fisheries (2012a). Environmental management and monitoring framework for marine aquaculture in South Africa. Report for the Department of Agriculture, Forestry, and Fisheries. EnviroFish Africa (Pty.) Ltd.

Republic of South Africa, Department of Agriculture, Forestry and Fisheries (2012b). South African Live Molluscan Shellfish Monitoring and Control Programme, Issue 3.

Republic of South Africa, Department of Environmental Affairs and Tourism (2007). Policy for the development of a sustainable marine aquaculture sector in South Africa.

Republic of South Africa, Department of Trade and Industry (2007). National Industrial Policy Framework (NIPF) [Online]. . http:// www.dti.gov.za/nipf/niPF-3aug.pdf [2010, November 17].

Rönnbäck, P., Bryceson, I., \& Kautsky, N. (2002). Coastal aquaculture development in eastern Africa and the western Indian ocean: prospects and problems for food security and local economies. Ambio, 31(7-8), 537-542.

Rouhani, Q., \& Britz, P.J. (2011). Participatory development of provincial aquaculture programmes for improved rural food security and livelihood alternatives. Water Research Commission Report TT 502/11.

Sadek, S., Rafael, R., Shakouri, M., Rafomanana, G., Ribeiro, F. L., \& Clay, J. (2002). Shrimp aquaculture in Africa and the Middle East: The current reality and trends for the future. Report prepared under the World Bank, NACA, WWF and FAO Consortium Programme on Shrimp Farming and the Environment. Work in Progress for Public Discussion. Published by the Consortium.

Saldanha Bay Municipality (2007). Integrated Development Plan 2006-2011 [Online]. http://www.capegateway.gov.za/Text/2008/ 4/idp_wc_saldanha_bay_2007.pdf [2010, November 15].

StatsSA (2011). Quarterly labour force survey: Quarter 3 (July to September) 2011; press statement. [Online]. Available: http:// www.statssa.gov.za/news_archive/press_statements/ QLFS\%20Q3-2011\%20Press\%20statement.pdf [2012, July 19].

Stenton-Dozey, J., Probyn, T., \& Busby, A. (2001). Impact of mussel (Mytilus galloprovincialis) raft culture on benthic macrofauna, in situ oxygen uptake, and nutrient fluxes in Saldanha Bay, South Africa. Canadian Journal of Fisheries and Aquatic Sciences, 58, 1021-1031.

Van Zyl, H., Barbour, T., Hamann, R. (2008). Assessment of socioeconomic impacts of Sea Harvest's operations on Saldanha Bay and the West Coast District. Unpublished report prepared for Sea Harvest Corporation Ltd by the Environmental Evaluation Unit, University of Cape Town.
Vorster, J., \& Heinecken, L. (2009). Socio-economic profile of Middelpos, Saldanha. Research report, Department of Sociology and Social Anthropology, University of Stellenbosch, South Africa.

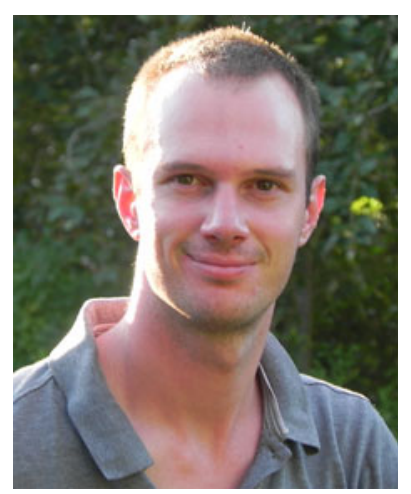

David Olivier is a $\mathrm{PhD}$ student in Sociology at Stellenbosch University. He graduated from Stellenbosch University with a Masters of Arts Degree in Sociology in 2011 having researched the employment potential of mariculture in Saldanha Bay. His interest in food security, food production and lowincome communities has led to his current focus on urban agriculture, a practical and professional interest. David volunteers for a civil society organisation in Cape Town that trains urban farmers in low-income communities. This experience inspired his $\mathrm{PhD}$ thesis on the role that civil society organisations play in the promotion of urban agriculture in Cape Town. This is his first publication.

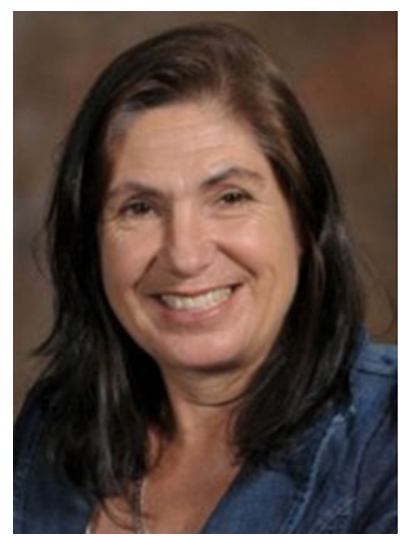

Prof Lindy Heinecken was formerly a researcher and Deputy Director of the Centre for Military Studies (CEMIS) at the South African Military Academy. She now serves as Associate Professor of Sociology in the Sociology and Social Anthropology Department of the University of Stellenbosch where she lectures in political and industrial sociology. The main focus of her research is in the domain of armed forces and society where she has published on a range of issues including gender integration, civil-military relations, military unionism, HIV/AIDS and security and more recently on the impact of private security on the military profession. She holds a MSocSc from the University of Cape Town and a $\mathrm{PhD}$ from Kings College, Department of War Studies, University of London. She serves on numerous academic boards, including the Council of the Inter-University Seminar on Armed Forces and Society (USA) and the International Sociological Association's (ISA) Armed Forces and Conflict Resolution working group. She is also one of the pool of specialists conducting research for the South African Army. 


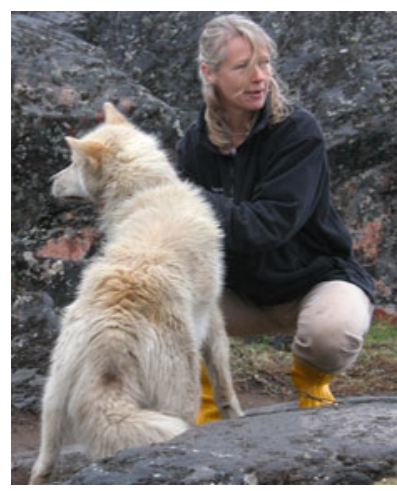

Dr Sue Jackson is a Research Associate at the University of Stellenbosch. She started her academic career in the $1980 \mathrm{~s}$ working on the ecology and physiology of penguins and albatrosses on Marion Island in the Southern Ocean. Since then, through three postdoctoral appointments at the universities of Minnesota, California at Los Angeles and Cape Town, and three different academic posts at the universities of the Witwatersrand and
Stellenbosch, she has researched topics ranging from the evolutionary physiology of birds, insects and Greenland sled dogs, to the adaptations of humans to high altitude. Currently, she is leading a multi-disciplinary project on oyster biology, focused on the South African industry and funded by the South African Department of Agriculture, Forestry and Fisheries, the National Research Foundation of South Africa, and the Centre of Invasion Biology at the University of Stellenbosch. This programme combines socio-economic work with assessments of the environmental factors influencing oyster growth in South African waters, and aims to contribute to the sustainability of marine aquaculture as an alternative to capture fisheries. In addition to the Pacific oyster that is farmed in South Africa, she is exploring the culture potential and genetics of indigenous species. 